\title{
The Role of Peacekeeping Operations: The Case of East Timor
}

\author{
Alla Borzova ${ }^{1,{ }^{*}}$ Johnatan Da Costa Santos $^{1, \mathrm{a}}$ Maria Nova Sibarani Dame ${ }^{1, \mathrm{~b}}$ \\ ${ }^{1}$ Department of Theory and History of International Relations, RUDN University, Moscow, Russia \\ ${ }^{a}$ E-mail: johnsantos@inbox.ru \\ ${ }^{b}$ E-mail: dame.sibarani@gmail.com \\ *Corresponding author. Email: borzova_ayu@pfur.ru
}

\begin{abstract}
The United Nations (UN) was established with the main objective of ensuring and promoting world peace. UN peacekeeping missions are the most visible instrument of the Organization's work in promoting world peace. In 1999, with the establishment of the Peace Mission in East Timor, the UN assumed all the functions of government in a peacekeeping mission with the purpose of developing the necessary bases for the birth of a State, which caught the attention of the international community. The present work investigates the process of independence, pacification, and (re)construction of East Timor, verifying how the UN's performance took place. In addition, it analyses the effectiveness of the missions implemented in order to bring peace, stability, and most notably independence.
\end{abstract}

Keywords: Indonesia, East Timor, Peace, United Nations, Independence.

\section{INTRODUCTION}

Both Indonesia and East Timor are undergoing similar tasks related to strengthening democracy, solving social problems and fighting against poverty. However, this scenario was never so easy for East Timor, who was colonized by Portugal for 400 years and occupied by Indonesia for 24 years. East Timor faced many challenges in order to gain independence and stablish a secure and 'stable' country for its population. With the UN's peacekeeping operations and the aid of countries like Australia, Brazil, New Zealand to tackle issues such as defense, social integration, science and education, and multilateral diplomacy, new policies were stablished. [11] This work analyses the role of the UN peacekeeping missions in East Timor, secondly, it will study the contributions the UN has brought to the newly formed country, and finally, it will examine the present relations between Indonesia and East Timor. This qualitative and bibliographic research is based on UN official documents, laws, and reports, as well as doctrines.

\section{INDONESIA AND EAST TIMOR}

With the fall of the dictatorial regime in Portugal, a number of its former colonies gained independence, and East Timor was one of them. However not long after on December 7, 1975 East Timor was occupied by Indonesian troops, and on July 17, 1976, East Timor was officially annexed as the 27 th province (Timor-Timur) by Indonesia.

As a result of the invasion many Timorese began a guerrilla war that divided the country, and the full-scale hostilities did not cease until 1980. Official documents state that even after a proclaimed "normalization" the Indonesian command in Dili acknowledged the existence of the leftist political group FRETILIN (Revolutionary Front for the Independence of East Timor) to have "security gangs" in settlements, villages, and other Timorese cities. [1]

The United Nations never recognized East Timor as part of Indonesia and several UN resolutions drew attention to the plight of East Timor and demanded the withdrawal of Indonesian troops in order to ensure the country's right of selfgovernance under UN control. 
On May fifth both Portugal and Indonesia together with UN members agreed to put an autonomy proposal to East Timor and by that the United Nations Mission in East Timor (UNAMET) (June-October 1999) was stablished to organize and conduct a popular referendum where the Timorese would decide the future of its territory by choosing between a special autonomy and its integration into the Republic of Indonesia, or its complete separation and independence. After many previous failed attempts, mostly due to Indonesia's interferences in the process more than $90 \%$ of voters took part in the referendum in August 30, 1999 and as a result $78.5 \%$ of them voted for its independence from Jakarta. After the referendum, Indonesia deployed into the territory of East Timor 15,000 soldiers, who carried out a massacre and mass murder in retaliation.

Indonesian actions dragged the attention of many political leaders around the globe. The European Union condemned Indonesian's actions and banned all military equipment and munition exportation to Indonesia and called for an immediate recognition of a sovereign East Timor as well as urged to the initiation of peacekeeping operations in the country. [8]

Indonesia also saw the worsening of its relations with Australia who in turn sent more than four thousand soldiers into East Timor on an operation known as the International Force for East Timor (INFTERFET) which was considered the largest Australian troop deployed since the Vietnamese war.

The Japanese government and international organizations such as the International Monetary Fund (IMF) and the World Bank alongside with the Asian Development Bank also imposed sanctions over Indonesia where $\$ 1.4$ billion in loan to Indonesia was put on hold and later the aid suspension was associated by the IMF to Human rights violations under the agreement of May 1999 between Lisbon and Jakarta. Under these circumstances Indonesia gave in and agreed to the deployment of an international force into East Timor. Due to this fact The UN Security Council unanimously voted in favour of a resolution on sending interethnic forces to East Timor and on the 21st of September 1999 the UN peacekeeping operation began, and 7,500 peacekeepers, mainly from Australia, Malaysia, New Zealand, landed in East Timor. [2]

\section{UN OPERATIONS IN EAST TIMOR}

In order to support East Timor, the UN Security Council began several missions to assist the country to re-establish, and on October 1999 the UN Transitional Administration (UNTAET) was stablished and served as a peacekeeping operation and as a political mission to help the country to gain political sustainability and economic independence. The United Nations Assistance Mission for East Timor (UNMISET) (May 2002 May 2005) was also of peacekeeping nature and was tasked with assisting the newly independent East Timor until all endeavours were completely transferred from Indonesian to Timorese authorities, allowing the new State to achieve fully independence.

Subsequently to the end of the peacekeeping missions, the UN dispatched a political mission (UNOTIL) to East Timor (May 2005 - August 2006) to assist in the development of important state structures and polices, such as personnel training on the issues of democracy and human rights. [3]

It is important to highlight that East Timor had to gain international credibility in order to build a strong nation and the only way to achieve that was by having a stable and secure country. Therefore, in August 2006 the United Nations Joint Mission (UNMIT) was created to support the government and state institutions to maintain stability, culture management, and promote political dialogue. Its tasks included assisting the national police, strengthening national capacities for the protection of human rights, improving the efficiency of the judicial system, and building capacity in postconflict peace-building. After the assassination attempt of its President and the Prime Minister in February 2008, the UN expanded its activities to strengthen the capacity of the national police and other institutional state structures. [4]

The UN's active stance on supporting East Timor on peace-making issues has contributed to some extent in political stabilization, the creation of state structures, respect for democracy and human rights in the country. Unfortunately, many issues related to education, the efficient use of natural resources and the development of the health care system have not yet been resolved. [5]

The recognition of East Timor as an independent state and its political stabilization raised questions on the development of relations with Indonesia. Both states signed a series of 
agreements aimed to improve their relations. The East Timor-Indonesia Boundary Committee has dealt with the demarcation of the territory and the solution of the problem of Timorese refugees who were in Indonesia. In 2005, the Indonesia-TimorLeste Commission of Truth and Friendship (CTF) was established to investigate crimes against humanity during the Indonesian occupation of the territory. [9] The CTF allowed the examination of documents related to the investigations of previous commissions: "Indonesian National Commission to Investigate Human Rights Violations in East Timor in 1999", "Indonesian Special Court for Human Rights in East Timor", "Special Groups for Serious Crimes" and "Commission for Reception, Truth and Reconciliation." In July 2008, the CTF submitted a report to the presidents of both countries. The Indonesian government and its president Susilo Bambang Yudhoyono endorsed the report and acknowledged human rights violation in East Timor.

Ever since, the relations between the two countries have improved markedly, Indonesia is now the leading trading partner for East Timor. In 2014, East Timor imported goods in the amount of $\$ 226$ million (36\% of imports), and exported only $\$ 240,000$. According to the data of 2017, Indonesia's exports to East Timor amounted to about $\$ 300$ million, and imports from this country are only \$2.5 million. For Jakarta, these are insignificant volumes, this trade represents only $0.07 \%$ of Indonesia's trade, and for Dili it is $31 \%$ of imports and $1.7 \%$ of its exports. Indonesia invested about $\$ 810$ million in eighteen projects in East Timor. [10] There are 24 state-owned companies, 400 private companies, about 7 thousand Indonesians residing in East Timor, and in turn, about 8 thousand students from East Timor receive education in Indonesia. [6] Indonesia also supports East Timor's fully entry into ASEAN. East Timor's Prime Minister described the relations with Indonesia as "mature" and it is clear that their relations have improved significantly in recent years after East Timor's independence. [7]

\section{CONCLUSION}

Based on the abovementioned we can see that despite the problems that East Timor faced during its years of colonization, the country has been surpassing to create a scenario of prosperity, independence and above all else the promotion and respect for human rights with the support of international institutions that aim for their protection.

On the other hand, we see a more solidary Indonesia, opened to new dialogues and relations. An Indonesia that today works 'closely' with East Timor to remedy the social problems caused by its militant and dictator policies, by investing in the country. It is also important to note that despite the social problems encountered in both countries, both have a unique goal - prosperity and stability.

\section{AUTHORS' CONTRIBUTIONS}

Dr. Alla Borzova conducted the analyses of the qualitative data here presented. Maria Nova Sibarani Dame was responsible to review the Indonesian literature in order to make a study of the events, and Johnatan da Costa Santos participated in writing, and in reviewing the principles of the peacekeeping operations in the region, and lastly, all authors conducted paper modification and editing.

\section{REFERENCES}

[1] KHAZANOV A.M. Vostochnyy Timor: dolgiy put' $\mathrm{k}$ nezavisimosti. //Istoriya $\mathrm{i}$ sovremennost'.2012. №2, c.113-129. [https://cyberleninka.ru/article/n/vostochnyytimor-dolgiy-put-k-nezavisimosti.] Khazanov A.M. East Timor: the long road to independence. // History and Modernity. 2012.№2, p.113-129.

[2] CUNHA, J.S. C. da 2001, The Questiono of East-Timor: Origens and Evolution,Brasília, FUNAG/IRBr.

[3] ASTRI Suhrke. Peacekeepers as nation builders: Dilemmas of the UN in East Timor.: $08 \quad$ Nov 2007 https://doi.org/10.1080/13533310108413917

[4] ONU-UNMIT (United Integrated Mission in Timor Leste URL: [https://www.emgfa.pt/pt/operacoes/missoes/ti mor-unmit] (Accessed: 10.10.2019)

[5] COSTA, Carlos Germano Ferreira; SILVA, Edson Vicente da. Peackeeping operations in East Timor: A bias that emphasizes learning. Interdisciplinary Applied Scientific Journal, Blumenau, v.9, n.2, p.14-25, TRII I 2015. ISSN 1980-7031. URL: [https://www.researchgate.net/profile/Carlos_ 
Ferreira_Costa3/publication/281934992.pdf] (Accessed: 10.10.2019).

[6] SPECIAL REPORT (ASPI) April 2011 Issue 39 A reliable partner Strengthening Australia - Timor-Leste relations. URL: [https://www.files.ethz.ch/isn/161621/6_59_1

2_PM_SR39_Timor-Leste.pdf] (Accessed: 07.10.2018).

[7] INDONESIA and Timor-Leste: from Occupation to Cooperation. URL: [https://www.hart-uk.org/blog/indonesia-andtimor-leste-from-occupation-to-cooperation/] (Accessed: 10.10.2019).

[8] INDONESIA and East Timor. URL: [https://www.hrw.org/legacy/wr2k/Asia05.htm] (Accessed:10.10.2019)

[9] STRATING, Rebecca. The Indonesia-TimorLeste Commission of Truth and Friendship: Enhancing Bilateral Relations at the Expense of Justice.// Contemporary Southeast Asia URL:[https://www.questia.com/library/journal /1G1-381587198/the-indonesia-timor-lestecommission-of-truth-and] (Accessed: 09.10.2019).

[10] JARRYD de Haan. A Friend in Need: TimorLeste Leader to Visit Indonesia. 27 JUNE 2018 Jarryd de Haan, Research Analyst, Indian Ocean Research Programme [http://www.futuredirections.org.au/publicatio $\mathrm{n}$ /friend-need-timor-leste-leader-visitindonesia/] (Accessed: 08.10.2019).

[11] DA COSTA SANTOS, Jonathan (2018). K voprosu o roli Brazilii $\mathrm{V}$ mirotvorcheskikh operatsiyakh OON. [About the role of Brazil in UN peacekeeping operations] Kazachestvo, (36), 109-117.

URL: [https://elibrary.ru/item.asp?id=38534154] (Accessed: 09.10.2019) 